монографія / [І. М. Боярко та ін.]. - Суми : Університетська книга, 2014. - 175 с.

4. Василенко Д. Ю. Методика оценки конкурентоспособности отечественных предприятий / Д. Ю. Василенко // Управління розвитком. - X : ВД «ІНЖЕК», 2012. - № 3. - С. 69-71.

5. Виханский О. С. Стратегическое управление / О. С. Виханский. - 2-е изд., перераб. и доп. - Москва : Гардарики, 2002. $-296 \mathrm{c}$.

6. Воронкова А. Э. Стратегическое управление конкурентоспособным потенциалом предприятия : диагностика и организация / А. Э. Воронкова. - Луганск : ЛНУ, 2000. $-310 \mathrm{c}$.

7. Герасимчук В. Г. Стратегічне управління підприємством. Графічне моделювання / В. Г. Герасимчук. - Київ : КНЕУ, 2016. - $360 \mathrm{c}$.
8.

Менеджмент конкурентоспроможності підприємства: стратегічний підхід та системні рішення : монографія / [О. В. Кендюхов та ін.] ; за заг. ред. О. В. Кендюхова - Донец. нац. техн. ун-т, Каф. стратег. упр. екон. розвитком. - Донецьк : Схід. вид. дім, 2014. $-201 \mathrm{c}$.

9. Стадник В. В. Стратегічне управління інноваційним розвитком підприємства / В. В. Стадник, М. А. Йохна. - Хмельницький : ХНУ, 2011. $327 \mathrm{c}$.

10. Shuki D. The Balanced Scorecard versus quality award models as strategic frameworks / D. Shuki // Total Quality Management \& Business Excellence. Abingdon : Taylor \& Francis, 2008. - Vol. 19. - Issue 6. - P. 583-593.

УДК:656.071(477)

\title{
ТЕОРІЇ УПРАВЛІННЯ РОЗВИТКОМ ЗАЛІЗНИЧНОГО ТРАНСПОРТУ
}

\author{
Островерх Г.С., аспірант (УкрДУЗТ)
}

У статті розглянуто наукові погляди вітчизняних та закордонних вчених щзодо проблеми управління розвитком підприємств залізничного транспорту. Також виділено декілька основних груп, в межах яких застосовуються заходи, які характеризуються схожість механізмів та інструментів реалізації для поліпшення та удосконалення роботи підприємств залізничного транспорту. Аналіз наукових здобутків у сфері управління розвитком підприємств залізничного транспорту, дозволив обтрунтувати необхідність впровадження комплексного механізму управління розвитком на підприємствах залізничного транспорту. Даний механізм повинен мати декілька рівнів реалізачії та включати сукупність елементів. Визначено, щуо в основі реалізації даного комплексного механізму управлінням розвитку повинні знаходитися стандарти державної транспортної політики, галузеві програми $i$ стратегіi розвитку, а також Міністерство інфраструктури Украӥни та самі підприємства залізничного транспорту.

Ключові слова: залізничний транспорт, управління, розвиток, стратегія розвитку, Міністерство інфраструктури України, галузеві програми. 


\title{
ТЕОРИЯ МЕХАНИЗМОВ УПРАВЛЕНИЯ РАЗВИТИЕМ ЖЕЛЕЗНОДОРОЖНОГО ТРАНСПОРТА
}

\author{
Островерх А.E., аспирант (УкрГУЖТ)
}

B статье рассмотрены научные взгляды отечественных и зарубежных ученых касательно проблемь управления развитием предприятий железнодорожного транспорта. Также выделено несколько основных групп, в рамках которых применяются меры, которые характеризуются сходство механизмов и инструментов реализачии для улучшения и совершенствования работь предприятий железнодорожного транспорта. Анализ научных достижений в области управления развитием предприятий железнодорожного транспорта, позволил обосновать необходимость внедрения комплексного механизма управления развитием на предприятиях железнодорожного транспорта. Данный механизм должен иметь несколько уровней реализации и включать совокупность элементов. Определено, что в основе реализации данного комплексного механизма управлением развития долэны находиться стандарты государственной транспортной политики, отраслевые программы и стратегии развития, а также Министерство инфраструктуры Украины и сами предприятия железнодорожного транспорта.

Ключевые слова: жнелезнодорожный транспорт, управление, развитие,стратегия развития, Министерство инфраструктуры Украины, отрослиые програмы.

\section{THEORY OF MECHANISMS OF MANAGEMENT BY DEVELOPMENT OF RAILWAY TRANSPORT}

\author{
Ostrovekh A.E., postgraduate (USURT)
}

The article deals with the scientific views of domestic and foreign scientists on the management of the development of rail transport enterprises. Several major groups are also identified, in which measures are used which are characterized by the similarity of mechanisms and implementation tools for improving and improving the operation of rail transport enterprises. The analysis of scientific achievements in the field of management of the development of railroad enterprises allowed to substantiate the need for the implementation of a comprehensive development management mechanism at railway enterprises. This mechanism should have several levels of implementation and include a set of elements. It is determined that the principles of the state transport policy, sectoral programs and development strategies, as well as the Ministry of Infrastructure of Ukraine and the enterprises of the railway transport, should be based on the implementation of this integrated mechanism for development management.

Keywords: railway transport, management, development, development strategy, Ministry of Infrastructure of Ukraine, sectoral programs.

Постановка проблеми та іï результатом яких повинно стати якісно зв'язки 3 науковими чи практичними нові умови функціонування галузі, завданнями. На сьогоднішній день досягнення ii техніко-економічного залізничний транспорт переживає період розвитку. Однак, сьогочасні реалії впровадження структурних реформ, функціонування ПАТ «Українська

Вісник економіки транспорту і промисловості № 59, 2017 
залізниця» вказують на існування ряду проблем, які істотно знижують рівень конкурентоспроможності залізничного транспорту, погіршують фінансовоекономічні результати його діяльності. Це застарілий рухомий склад, об'єкти колійної інфраструктури, неефективні методи управління галуззю, низький рівень безпеки та якості процесу перевезень, їх невідповідність міжнародним стандартам залізничних перевезень. Все це свідчить про необхідність дослідження теорій розвитку управління залізничним транспортом.

Аналіз досліджень і публікацій Вирішенню проблем, пов'язаних із забезпечення ефективності функціонування підприємств залізничного транспорту, визначенню сучасних методів управління розвитком залізничного транспорт приділяється увага 3 боку багатьох вітчизняних учених. Серед них особливим здобутком відзначаються праці В.Л. Диканя[8], Н.В. Якименко[4], Л.Л. Калініченко[6] та ін.

Цими науковцями зроблено величезний вклад у розрізі окремих аспектів вирішення даної проблеми. Однак наявний фінансовий та технікотехнологічний стан залізничного транспорту, свідчить про доцільність продовжувати дослідження 3 окресленого напрямку.

Метою статті с дослідження існуючих теорій управління розвитком залізничного транспорту, та формування напрямку їх удосконалення.

Викладення основного матеріалу. Головною ознакою стійкого стану підприємств залізничного транспорту $\epsilon$ його розвиток. У загальновживаному значенні під розвитком розуміють процес удосконалення тих чи інших елементів суспільних відносин, матеріально-речових складових суспільства або соціальноекономічних i матеріальних систем у цілому, перехід до принципово нових якісних характеристик.
У цьому сенсі розвиток слід розуміти як багатовимірний процес глибокої модернізації та переорієнтування всієї економічної, а також соціальної системи. Він передбачає зростання доходів від виробництва та перевезень, здійснення радикальних змін в інституційній, соціальній i адміністративній структурах.

Наукові погляди вітчизняних та закордонних вчених щодо проблеми управління розвитком послуг підприємств залізничного транспорту характеризуються різноманіттям. В цілому ï можна поєднати у декілька основних груп, в межах яких застосовуються заходи, які характеризуються схожістю механізмів та інструментів реалізації. Такими групами можуть бути:

a) група фінансових підходів

Розвиток управління підприємств залізничного транспорту безпосередньо залежить від рівня забезпеченності фінансовими ресурсами. Їх формування i обсяг залежить від вирішення проблем визначення витрат на перевезення та механізмів тарифоутворення на послуги, проблем компенсації витрат на перевезення пільгового контингенту, механізмів державного фінансування програм розвитку залізничного транспорту тощо.

Наукова література налічує достатньо велику кількість наукових праць відносно методів розрахунку собівартості перевезень, додаткових послуг, розподілу витрат за основними складовими забезпечення процесу вантажних та пасажирських перевезень, ціноутворення. Все частіше методи розрахунку витрат на залізничному транспорті зазнають критики, так як не дозволяють визначити частку кожного можливого учасника перевезень у загальній собівартості пасажирських перевезень; врахувати вплив зміни вартості кожного виду ресурсів, задіяних на певній окремій операції здійснення 
перевезень, на загальну вартість перевезень пасажирів; врахувати коливання розміру собівартості за кожною ділянкою слідування поїзда; врахувати показники потенціалу галузі (ділянок, станцій, структурних підрозділів, підприємств тощо). Саме тому базові методи розрахунку собівартості зазнають постійного вдосконалення 3 боку науковців.

Наприклад, Колеснікова Н.M. пропонує в структурі собівартості за початково-кінцевими й рухомими операціями відокремити інфраструктурну, вагонну, локомотивну (магістральну та маневрову) складові. Застосувавши диференційно-затратний метод, який спирається на моделі диференційованого ціноутворення, використання як тарифної бази собівартості, економічно-обгрунтованої врахування ціновоі еластичності попиту, пропонує моделі розрахунку базового тарифу класів вантажів та базового тарифу інтегрованого пасажирського перевезення [1, с. 13-17].

Вдосконаленню

методів розрахунку собівартості присвячено праці Пасічника B.I., який акцентує увагу на розрахунку одиничних витратних ставок 3 використанням повних витрат по кожній статті номенклатури. Вчений пропонує замість заробітної плати як елемента витрат, що використовується для розподілу загальногосподарських витрат, використовувати новий показник, який визначає частку загальних для всіх галузей господарства витрат у сумі основних витрат у кожній одиничній витратній ставці [2, с. 119-152].

Розкриваючи

проблематику розрахунку собівартості пасажирських перевезень, Познякова О. [3, с. 154-157] вважає за доцільне застосовувати організаційно- матричний метод, особливістю якого $€$ наявність трьох складових формування собівартості перевезень:

1) операції, роботи чи послуги узагальненого технологічного процесу перевезення пасажирів певним пасажирським потягом за конкретним маршрутом;

2) місця виникнення витрат процесу територіального переміщення пасажирів, відповідно, за кожною операцією, роботою чи послугою узагальненого технологічного процесу;

3) витрати, що виникають за кожною операцією, роботою чи послугою узагальненого технологічного процесу у визначеному місці пасажирського перевезення.

Впроваджуючи різноманітні механізми розвитку послуг, слід чітко розуміти, що їх ціллю не $є$ сам процес розвитку послуги, а ті результати, які отримає підприємство за результатами їх реалізації. Відповідно до цього в процесі тарифоутворення потрібно враховувати, що розмір тарифів має позитивно впливати на основні показники діяльності суб'єктів господарювання.

Як стверджує Якименко Н.В., має бути застосований партнерськоадаптивний підхід до тарифоутворення, який, на відміну від існуючих, передбачає, по-перше, узгодження тарифоутворення на послуги залізничного транспорту 3 тенденціями та завданнями розвитку економіки при одночасній фактичній підтримці держави, яка $\epsilon$ власником інфраструктури; по-друге, введення постійно діючого механізму адаптації тарифів до змін зовнішнього середовища функціонування залізничного транспорту [4, с. 194]. Розширення меж розуміння проблематики підготовки кадрів для залізничного транспорту 3 урахуванням сучасних тенденцій та проблем функціонування вітчизняних підприємств залізничного транспорту дозволило розробити пропозиції щодо впровадження системи галузевого інноваційного навчання на залізничному транспорті, мета якої підготовка висококваліфікованого персоналу для вирішення стратегічних завдань розвитку

Вісник економіки транспорту і промисловості № 59, 2017 
галузі [5, с. 212-213].

Відомим вченим в галузі управління персоналом підприємств залізничного транспорту є Калініченко JI.JI. Проведений вченим аналіз стану економічної безпеки залізничного транспорту довів наявність численних чинників, що негативно впливають на функціонування підприємств галузі та спричиняють виникнення кризових ситуацій. Кадрова безпека визначена такою, яка має домінуюче положення відносно інших елементів системи безпеки підприємств залізничного транспорту. На думку науковця, структура системи управління персоналом на підприємствах залізничного транспорту має включати підсистеми маркетингу, планування, прогнозування, розвитку персоналу, підсистему аналізу і розвитку засобів мотивації праці, підсистему розвитку соціальної інфраструктури, аналізу та регулювання трудових відносин, підсистему забезпечення конкурентоспроможності колективу тощо [6, c. 100].

Федоров Г.В., досліджуючи методи організації процесу професійного розвитку персоналу на залізничному транспорті, зазначає, що підвищення ефективності діяльності підприємств залізничного транспорту обумовлюється підготовкою, перепідготовкою та підвищенням кваліфікації менеджерів i спеціалістів, так як саме ці категорії персоналу впливають на організацію виробництва в умовах реформування галузі. Науковець пропонує одним 3 напрямів професійного розвитку персоналу галузі визначити застосування електронного навчання [7, с. 20].

Окрему групу наукових праць складають ті, які вирішують проблему оновлення та модернізації основних фондів підприємств залізничного транспорту, технологій їх ремонту та обслуговування. Основним напрямом оновлення рухомого складу підприємств залізничного транспорту Дикань B.JL,
Корінь М.В. визначають розвиток транспортного машинобудування на ринкових засадах 3 одночасним посиленням державного регулювання [8].

Спеціалісти Інституту економіки та прогнозування НПН України, Карпов В.М. i Никифорук O.I. пріоритетними напрямами оновлення рухомого складу залізничного транспорту вважають: поперше, розвиток виробництв на вітчизняних локомотивобудівних та вагонобудівних підприємствах; по-друге, поетапне освоєння та впровадження прогресивної техніки нового покоління та ефективних технологій, що передбачає укладання угод із зарубіжними компаніями на поставку рухомого складу 3 подальшою локалізацією виробництва в Україні [9, с. 166].

\section{б)група маркетингових підходів}

Відомим фахівцем в сфері маркетингу на об'єктах транспорту $є$ Аксьонов I. М., який головною задачею маркетингу в сфері перевезень визнає вміння правильно визначати потреби споживачів транспортних послуг та задовольняти їх більш ефективно, допомагати досягненню узгодженості між виробниками транспортної продукції та їх споживачами. Саме тому основними інструментами-засобами називає пошук ідей.

Отже, інструментами маркетингу є:

1) пошук нових видів послуг, які сприяють покращенню обслуговування вантажовласників i пасажирів, зміна системи обслуговування пасажирів, навчання персоналу методів швидкого i якісного надання послуг, внесення пропозицій про розширення постачальників послуг 3 метою скорочення часу надання послуг;

2) забезпечення якості послуг за рахунок надання ним нових властивостей та змісту;

3) розширення асортименту послуг (доставка «від дверей до дверей», інформування вантажовласників про прибуття вантажів, приймання замовлення 
та оформлення провізних документів у зручний час тощо;

4) ціна на послуги, при встановленні якої враховується рівень сервісу, який отримується на різних етапах перевезення;

5) система маркетингових комунікацій: персональна (обумовлюється поведінкою співробітників, які контактують зі споживачами 3 моменту отримання довідки до доставки вантажу або пасажира до місця призначення) i масова (реклама) [10, с. 26-29].

Маркетингова діяльність в сфері транспортних послуг, на думку авторів $[11$, с. 33], має забезпечувати надійну i достовірну інформацію про транспортний ринок, структуру i динаміку попиту, бажання вантажовласників, можливості конкурентних видів транспорту, а також створення таких транспортних послуг (основних та додаткових), які відповідали б вимогам ринку і задовольняли споживчий попит. Відносно діяльності залізниць визнається необхідність перетворення відділів планування перевезень, служби перевезень у відділи транспортного маркетингу, передавши їх у вантажні служби, або створення окремої комерційно-маркетингової служби залізниць.

Російський вчений Борщ В.M., досліджуючи маркетингові стратегії просування транспортних послуг на ринках перевезень, звертає увагу на такі інструменти просування (які одночасно $€$ інструментами розвитку послуг залізничного транспорту) як впровадження сервісних інновацій, створення програм лояльності в сегменті пасажирських i вантажних перевезень, розвиток інформаційних інтернеттехнологій; інноваційно-орієнтовані маркетингові технології просування [12, с. 19].

Також уваги заслуговує точка зору на проблему маркетингу на залізничному транспорті, яка викладена Зоріною O.I. Вчена вважає за необхідне створити на залізничному транспорті інтегровані маркетингові структури, які будуть спільно з іншими службами здійснювати заходи, що спрямовані на максимальне виконання вимог споживачів щодо видів та якості послуг, забезпечуючи тим самим конкурентоспроможність залізничного транспорту [13, с. 193].

Таким чином, за результатами вивчення маркетингових механізмів розвитку транспортних послуг залізничного транспорту можна констатувати, що вони опосередковано впливають на розвиток послуг підприємств залізничного транспорту виконуючи роль непрямих, a забезпечуючих механізмів.

Зробивши аналіз наукових досліджень та узагальнюючі різні погляди на проблеми, пов'язані із забезпеченням ефективності функціонування залізничного транспорту України, можна виділити ще одну групу механізмів, яка впливає на управління розвитком залізничного транспорту - організаційнорозподільні механізми.

Управлінський підхід до збалансованого розвитку повинен включати в себе загальні управлінські аспекти та механізми, які містять принципи, методи, функції управління i організаційні структури, управлінські рішення, а також технології процесів управління, наукову організацію праці та інші сполучні елементи управління розвитком підприємств залізничного транспорту.

Формування механізмів i умов вироблення цілей управління розвитком залізничного транспорту, які відповідають цінностям, цілям і пріоритетам розвитку суспільства сьогодні і в перспективі.

Важливу роль у досягненні сталого розвитку сучасного підприємства відіграє інтенсивне і збалансоване використання його потенціалу як основи, на якій будуються і реалізуються його зовнішні і внутрішні відтворювальні процеси. У зв'язку з цим актуалізується необхідність формування багаторівневої системи

Вісник економіки транспорту і промисловості № 59, 2017 
управління розвитком підприємств залізничного транспорту, яка має грунтуватися на раціональному використанні і побудові взаємозв'язків між різними видами і рівнями напрямів діяльності, ієрархії управління, сферами функціональної відповідальності, ресурсами.

\section{Підприємства}

транспорту України в останні роки втратили конкурентні позиції на транспортному ринку. Це стало наслідком (окрім інших вагомих причин - нестача фінансових ресурсів, старіння основних фондів, низька інвестиційна привабливість тощо) значного невдоволення споживачів послуг залізничного транспорту їх вартістю та якістю. Саме тому, актуальним $\epsilon$ завдання управління розвитком ПАТ «Українська залізниця».

Враховуючи, що керівники підприємств потребують серйозної методичної допомоги в прийнятті управлінських рішень, насамперед у виборі стратегічних напрямів діяльності, постає необхідність розробки методологічних засад побудови процесу управління сталим розвитком підприємств. Це вплине на швидке прийняття ефективних рішень, через вибір відповідних критеріїв, методів, технологій, моделей, механізмів реагування та взаємодії елементів.

Висновок Аналіз наукових здобутків у сфері управління розвитком підприємств залізничного транспорту дозволив обгрунтувати необхідність впровадження комплексного механізму управління розвитку підприємств залізничного транспорту. Встановлено, що організаційно-розподільчий механізм повинен мати декілька рівнів реалізації та включати сукупність механізмів, які за допомогою сучасних методів управління процесами забезпечення розвитку послуг та при належному інформаційному забезпеченні зможуть впливати на об'єкти управління, а саме: послугу, суб'єкти господарської діяльності, транспортно- логістичну інфраструктуру цим самим забезпечуючи соціально-економічний розвиток галузі, регіонів та економіки країни в цілому. Визначено, що в основі реалізації даного комплексного механізму розвитку послуг підприємств залізничного транспорту повинні знаходиться норми державної транспортної політики, галузеві програми і стратегії розвитку в сфері залізничного транспорту, а суб'єктами його реалізації повинні стати керівники Міністерства інфраструктури, Укрзалізниці, підприємств залізничного транспорту.

\section{СПИСОК ВИКОРИСТАНИХ ДЖЕРЕЛ}

1 Колеснікова Н.М. Методологопрактичні основи ціноутворення на залізничному транспорті України: автореф. дис. на здобуття наук, степеня докт. екон. наук : спец. 08.00.04 «Економіка та управління підприємствами» /Н.М. Колеснікова. Київ, 2008. - 34 с.

2 Пасічник B.I. Методи розрахунку собівартості перевезень: навчальний посібник/ В.I. Пасічник. - К.: Основа, 2005. - С. 119 -152.

3Познякова О. Формування собівартості перевезень за організаційноматричним методом / О. Познякова // Збірник наукових праць ДЕТУТ. Сер. Економіка і управління. - 2011. - Вип. 17.CI 52-157.

4Якименко Н.В. Системноструктурний підхід до формування інституційного середовища залізничного транспорту / Н.В. Якименко // Вісник економіки транспорту і промисловості. 2012. - № 39. - С. 190 - 198.

5Якименко Н.В. Управління економічним зростанням залізничного транспорту в умовах розвитку транспортного ринку України: монографія /Н.В. Якименко. - Х.: УкрДАЗТ, 2012. $437 \mathrm{c}$

6 Калініченко

Л.Л. Методологічний підхід до управління 
персоналом підприємств залізничного транспорту в умовах реформування галузі: монографія / Л.Л. Калініченко. - Х.: УкрДАЗТ, 2012. - 420 с.

7 Федоров Г.В. Методы организации процесса профессионального развития персонала на железнодорожном транспорте : автореф. дис. на соискание учен, степени канд. экон. наук: спец.: 05.02.22 «Организация производства» /Т.В. Федоров. - Москва, 2005. - 26 с.

8 Дикань В.JI. Забезпечення конкурентоспроможності промислових підприємств в умовах функціонування мережі міжнародних транспортних коридорів / В.JI. Дикань, М.В. Корінь // Вісник економіки транспорту i промисловості. - 2012. - № 38. - С. 156 162.

9Карпов В.М. Стан, проблеми та перспективи оновлення залізничного рухомого складу України / В.М. Карпов, O.I. Никифорук // Формування ринкових відносин в Україні. - 2012. - № 6. - С. 160166.

10 Аксенов И.М. Маркетинг на объектах транспорта: монография / И.М. Аксенов. - Нежин: ООО «Видавництво «Аспект-поліграф», 2006. - 336 с.

11 Балалаев А. С. Основы маркетинга на транспорте: учебное пособие/А.С. Балалаев, С.А. Балалаев, И.И. Климентьева. - 2-е изд., перераб. и доп. - Хабаровск: Издательство ДВГУПС, 2013. - $162 \mathrm{c}$.

$$
12 \text { Борщ В.Н. Разработка }
$$
маркетинговой стратегии продвижения транспортных услуг на рынках железнодорожных и авиаперевозок : автореф. дис. на соискание учен, степени канд. экон. наук: спец.: 08.00 .05 «Экономика и управление народным хозяйством » / В.Н. Борщ. - Волгоград, 2013. - $27 \mathrm{c}$.

13 Зорина Е.И. Применение концепции интегрированного маркетинга на железнодорожном транспорте в условиях реформирования отрасли / Е.И.Зорина, Е.Э. Наумова. А.И. Антонова // Бизнес-информ. - 2012. - № 8. - С. 192 195.

УДК 167:656.2.007

КОГНІТИВНИЙ СИНТЕЗ У ПРИЙНЯТТІ РІШЕНЬ ПЕРСОНАЛОМ СТРУКТУРНИХ ПІДРОЗДІЛІВ ЗАЛІЗНИЦЬ, ВПРОВАДЖУЮЧИХ ПЕРСПЕКТИВНІ ІНТЕНЦЙНІ СИСТЕМИ КЕРУВАННЯ РУХОМ ШВИДКІСНИХ ПОїЗДІВ

\author{
Петрушов В. М., о.ф.н., професор (УкрДУЗТ)
}

У статті автор продовжуе розглядати проблему втілення в практику керування залізничним транспортом в умовах значного зростання швидкості поїздів інтенційних систем, у складі яких використовуються інтерфейси нового покоління (так звані нейроком' ютерні інтерфейси). Акцент робиться на питанні когнітивного синтезу інформаційних компонент, що входять до змісту рімень, які приймаються керуючим персоналом.

Ключові слова: інтенціональність, інтенційне керування, оптимальне рішення, когнітивний синтез, інтерфейс «мозок-комп'ютер», індукційний образ, інтенційна система керування, енактивізм, віртуальна реальність. 